Kumawula, Vol. 3, No.3, Desember 2020, Hal 398 - 404

DOI: https://doi.org/10.24198/kumawula.v3i3.27277

ISSN 2620-844X (online)

Tersedia online di http://jurnal.unpad.ac.id/kumawula/index

\title{
PEMETAAN JARINGAN KOMUNIKASI BISNIS USAHA EKSTRAKTIF (PERTANIAN, PERIKANAN DAN PETERNAKAN)
}

\author{
Zaenal Muttaqin $^{1^{*}}$, Iwan Sukoco ${ }^{2}$, Luthfi Thirafi ${ }^{3}$ \\ ${ }^{1}$ Departemen Ilmu Administrasi Bisnis, Fakultas Ilmu Sosial dan Ilmu Politik Universitas Padjadjaran \\ ${ }^{2}$ Departemen Ilmu Administrasi Bisnis, Fakultas Ilmu Sosial dan Ilmu Politik Universitas Padjadjaran \\ ${ }^{3}$ Departemen Ilmu Administrasi Bisnis, Fakultas Ilmu Sosial dan Ilmu Politik Universitas Padjadjaran \\ *Korespondensi : zaenal.muttaqin@unpad.ac.id
}

\begin{abstract}
The natural wealth of Cintaratu Village is very abundant. Their potential can support the extractive businesses sector such as agriculture, fisheries and livestock. To optimize the existing potential we need to understand the communication patterns that are carried out between business actors. This research uses census to collect data related to the source of the Cintaratu Village's extractive business. The questionnaire used as a tool to collect the data. Validation and additional data collection is done through the implementation of Focus Group Discussions. Data is used to compile a Communication Network Map. This research shows that some business actors do not have the capabilities to make sales to end consumers and there are still brokers in the structure of business communication. Counseling related to marketing strategies and the use of the latest technology is needed to optimize the potential of extractive businesses sector.
\end{abstract}

Keywords: Communication Network; Extractive Business; Animal Husbandry; Agriculture; Fishery

\begin{abstract}
ABSTRAK
Kekayaan alam yang dimiliki Desa Cintaratu sangatlah berlimpah. Potensi yang dimiliki dapat menyokong sektor ekonomi dan usaha ektraktif seperti pertanian, perikanan dan peternakan. Untuk mengoptimalkan potensi yang ada kita perlu memahami pola komunikasi yang dilakukan antar pelaku usaha. Penelitian ini menggunakan metode sensus untuk mengumpulkan data terkait sumber usaha ektraktif Desa Cintaratu. Kuisioner menjadi alat yang digunakan untuk mengumpulkan data tersebut. Validasi dan pengumpulan data tambahan dilakukan melalui pelaksanaan Focus Group Discussion. Data digunakan untuk menyusun Peta Jaringan Komunikasi Bisnis. Penelitian ini menunjukkan sebagian pelaku usaha tidak memiliki akses untuk melakukan penjualan kepada konsumen akhir serta masih terdapat calo dalam struktur komunikasi bisnis yang dilakukan. Penyuluhan terkait strategi marketing dan penggunaan teknologi terbaru diperlukan untuk mengoptimalkan potensi yang dimiliki oleh pelaku sumber usaha ektraktif di Desa Cintaratu.
\end{abstract}

\section{PENDAHULUAN}

Desa Cintaratu merupakan salah satu Desa yang terletak di Kecamatan Parigi, Kabupaten Pangandaran, Jawa Barat. Desa Cintaratu memiliki luas wilayah sebesar 1.029 Ha. Desa Cintaratu memiliki potensi dalam bidang pertanian, peternakan dan perikanan yang cukup besar. Hal ini didukung oleh kondisi geografis Desa Cintaratu yang terdiri atas sawah dan ladang sebesar 288,61 Ha, perkebunan rakyat sebesar 116,72 Ha dan hutan sebesar 23 Ha. Kehadiran sawah dan ladang serta hutan menjadi pendukung hadirnya sektor peternakan yang berpotensi untuk berkembang. Disebelah selatan Desa Cintaratu, terdapat hamparan sawah yang terbentang berbatasan dengan Desa Cibenda dan Desa Bojong. Hamparan sawah tersebut merupakan sumber daya yang sangat potensial untuk mendukung 
sektor pertanian Desa Cintaratu. Potensi pertanian juga didukung oleh curah hujan yang sangat tinggi mencapai 200 mm, menjadikan Desa Cintaratu tergolong memiliki curah hujan sangat deras. Selain itu Desa Cintaratu sebagai bagian dari Kabupaten Pangandaran memiliki akses terhadap laut dan pantai yang dimiliki Kabupaten Pangandaran. Laut seluas 67.340 Ha dan pantai sepanjang $91 \mathrm{Km}$ menyimpan potensi hasil laut yang melimpah, menjadikan sektor perikanan sebagai sektor yang menjanjikan di Desa Cinta ratu.

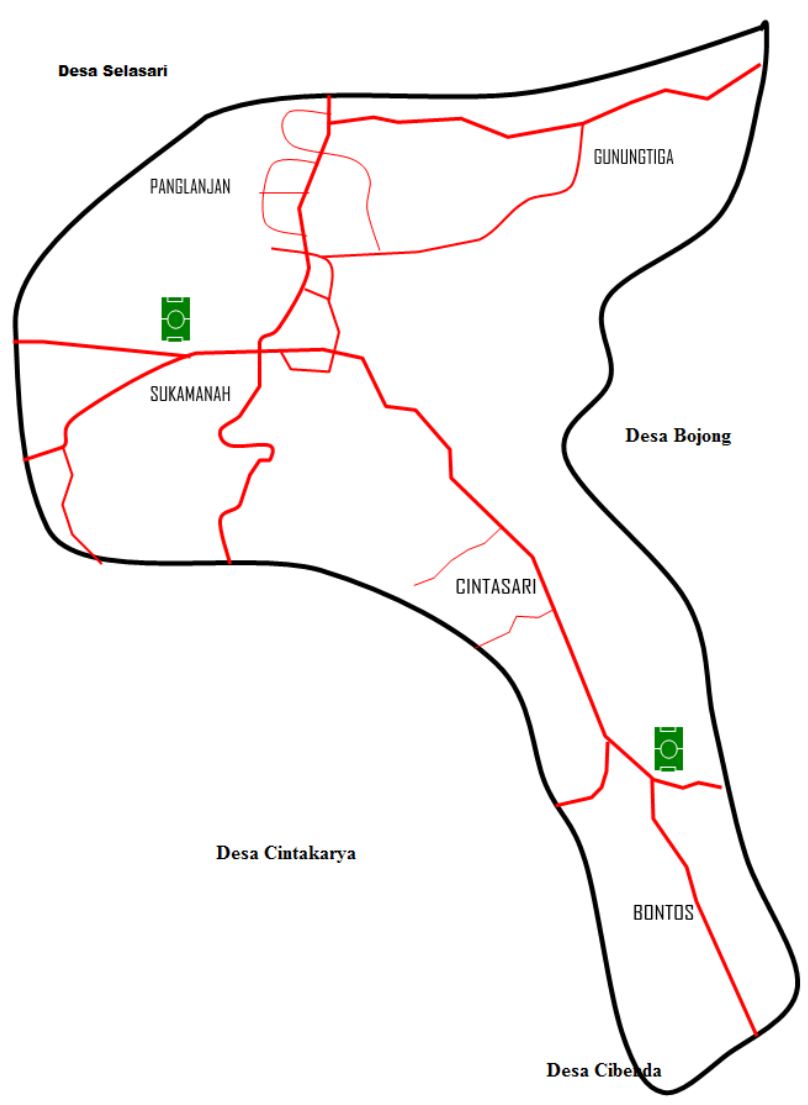

Gambar 1. Peta Desa Cintaratu

Sumber: https://cintaratu.desa.id/geografis/

Besarnya potensi yang dimiliki oleh Desa Cintaratu tidak didukung dengan Sumber Daya Manusia yang mampu memanfaatkan potensi tersebut dengan optimal. Salah satu contoh yang dapat diambil adalah kurangnya tenaga ahli dibidang teknologi pertanian. Hal ini dapat ditemui dalam pengembangan tanaman holtikultura seperti cabai. Pun begitu, masalah ini mulai teratasi dengan hadirnya sosialisasi terkait dengan kemajuan pertanian. Disisi lain, bidang peternakan juga memiliki permasalahan tersendiri. Salah satu masalah yang muncul adalah kurangnya kesadaran terhadap kebersihan lingkungan. Kendati telah ada upaya untuk mengolah sampah dan limbah ternak, namun dampak pada kebersihan lingkungan masih dapat terlihat. Sektor perikanan juga tidak terlepas dari permasalahan seperti ini. Penggunaan metode penangkapan ikan yang tidak ramah lingkungan masih dapat ditemui dan dapat mengancam keberlangsungan ekosistem maupun memangkas potensi tumbuhnya sektor perikanan.

Potensi yang dimiliki oleh Desa Cintaratu dapat dimanfaatkan untuk mendukung sektor pariwisata di Kabupaten Pangandaran. Pemanfaatan potensi masyarakat dalam pengelolaan pariwisata seperti ini sering disebut dengan Community Based Tourism (Abdoellah et al., 2019). Salah satu hal yang harus dilakukan untuk mengembangkan potensi lokal adalah pengembangan ekonomi masyarakat, disamping penyeimbangan pelestarian alam dan penguatan kapasitas pemerintah (Abdoellah et 
al., 2019). Hal ini menjadikan pengetahuan mengenai jaringan komunikasi bisnis sebagai sesuatu yang penting. Jaringan komunikasi bisnis sendiri adalah jaringan komunikasi atau relasi yang dimiliki pemilik usaha untuk melakukan aktivitas penyaluran barang hasil produksi kepada pasar atau konsumen yang ditargetkan. Jaringan komunikasi bisnis juga meliputi relasi terkait supply bahan baku untuk kegiatan produksi. Melalui pemetaan jaringan komunikasi bisnis, tidak hanya pola komunikasi saja yang akan tergali. Profil sumber usaha ekstraktif akan terdokumentasi dengan lebih lengkap. Data yang diperoleh dapat digunakan sebagai acuan untuk mengembangkan potensi sumber usaha ekstraktif di Desa Cintaratu yang akan berdampak pada perkembangan ekonomi masyarakat.

\section{METODE}

Metode yang digunakan dalam kegiatan ini meliputi tiga hal yakni sensus, depth interview dan analisa jaringan. Secara umum penelitian ini dilakukan dengan pola sebagai berikut:

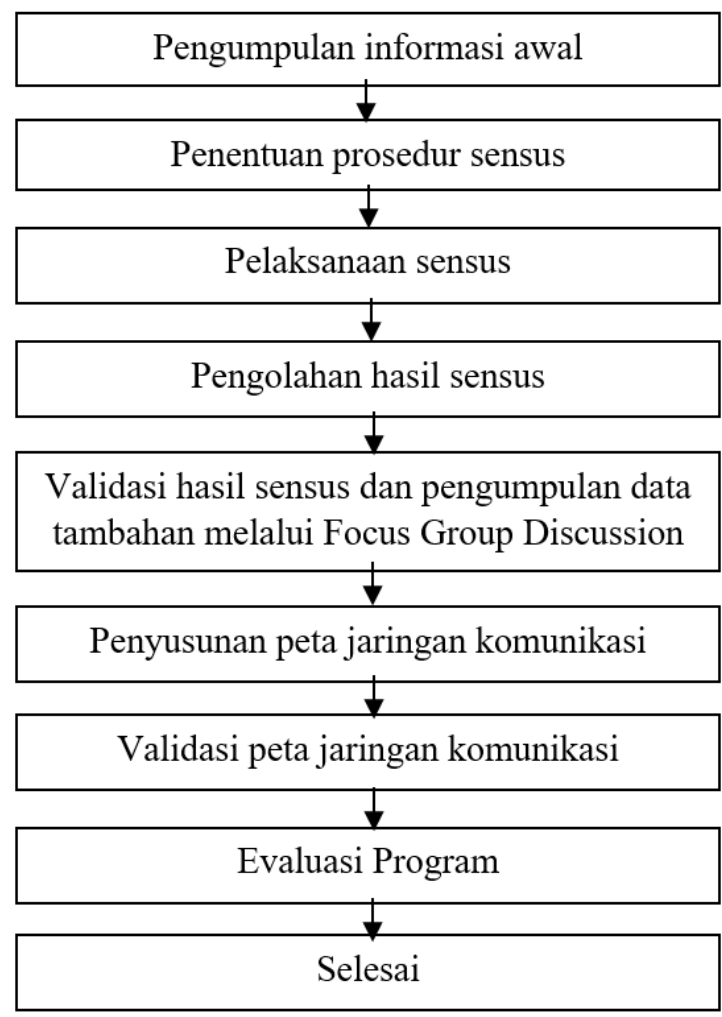

Gambar 2. Alur Kerja Program

Sensus menurut KBBI adalah penghitungan jumlah penduduk, ekonomi dan sebagainya yang dilakukan secara serentak dan bersifat menyeluruh dalam batas wilayah tertentu. Untuk itu, dalam kegiatan ini akan dilakukan upaya sensus yang meliputi masyarakat Desa Cintaratu, khususnya pelaku bisnis ekstraktif. Metode selanjutnya adalah depth interview. Depth interview memerlukan adanya serangkaian pertanyaan/kuisioner yang bertujuan untuk menggali informasi sedalamdalamnya terkait dengan jaringan komunikasi bisnis usaha ekstraktif di Desa Cintaratu. Depth interview akan ditujukan kepada masyarakat Desa Cintaratu serta tokoh-tokoh yang terlibat dalam usaha ekstraktif. Informasi yang didapat akan menjadi bahan dalam pemetaan jaringan komunikasi bisnis serta penentuan jenis intervensi yang dapat digunakan untuk meningkatkan komunikasi diantara usaha-usaha ekstraktif di Desa Cintaratu. Dalam melakukan validasi terhadap hasil yang diperoleh, dilakukan Focus Group Discussion (FGD) dengan pelaku bisnis ekstraktif di Desa Cintaratu. Aktivitas ini sekaligus menggali informasi-informasi lain yang belum diperoleh saat wawancara/depth interview. Metode selanjutnya yang digunakan adalah metode analisis jaringan. Analisis jaringan dilakukan untuk membantu mengurai rantai komunikasi dalam kegiatan sumber usaha ekstraktif di Desa Cintaratu. Selanjutnya rantai komunikasi tersebut disusun menjadi peta jaringan komunikasi bisnis. Tokoh, aktor dan struktur jaringan yang terjalin juga dapat diidentifikasi melalui peta jaringan ini.

\section{HASIL DAN PEMBAHASAN}

. Hasil pengumpulan data menunjukkan pada sektor pertanian terdapat beberapa kelompok tani. Berikut daftar kelompok tani tersebut :

- Mitra tani

o Tanaman pangan: padi, jagung, kacang tanah

o Hortikultura: sawi, mentimun, kacang panjang, cabai merah, cabai rawit, terong

- Harapan I

o Tanaman pangan: padi, jagung, kacang tanah 
- AT Harapan

o Hortikultura: kacang panjang, cabai merah, cabai rawit, mentimun, terong hijau dan ungu, buncis, paria

o Tanaman pangan: padi

o Holtikultura: kacang panjang

- Karya Taruna II

o Tanaman pangan: padi

o Holtikultura: kacang panjang

- Kelompok Wanita Tani

o Tanaman pangan: jagung

o Hortikultura: cabai rawit, terong, kangkung, sawi, paria, ubi jalar, pisang

Mayoritas kelompok tani melakukan penjualan kepada pengepul, hanya Kelompok Wanita Tani saja yang melakukan penjualan langsung kepada konsumen individu. Beralih ke sektor Peternakan, terdapat pelaku usaha dalam bentuk kelompok peternak dan pelaku usaha individu. Berikut daftar peternak di Desa Cinta Ratu :

- Kelompok ternak Bintang Harapan

- Ternak ayam Ibu Aat

- Ternak ayam Ibu Esih

- Ternak ayam Bapak Wiwin Sarwin

- Ternak sapi Bapak Rupin

- Ternak dan penggemukan sapi Bapak Dede pengembangbiakan sapinya sendiri, bahkan telah sanggup menjadi supplier bagi peternak yang lain. Usaha ternak ayam kampung milik Ibu Esih melakukan penjualan kepada konsumen akhir dan pengepul, sementara itu peternak ayam lainnya menjual melalui perantara. Sektor terakhir adalah sektor perikanan, berikut daftar pelaku usaha sektor perikanan :

- Ternak ikan Bapak Hamdan (ikan mas, ikan nila, ikan nilem, ikan tawes, ikan gurame)

- Ternak Ikan Bapak Nuryadi (ikan mas, ikan mujair)

- Ternak Ikan Bapak Hamid (ikan mas, ikan mujair, ikan gurame, ikan tawes)

- Ternak Ikan Bapak Kastjah (pembesaran, pertengahan, dan benih ikan mas)

Pada sektor perikanan hanya Bapak Kastjah saja yang melakukan penjualan langsung kepada konsumen akhir. Pelaku usaha lainnya melakukan penjualan melalui perantara sebelum komoditas mereka diterima oleh konsumen akhir. Secara umum, sektor usaha ekstraktif di Desa Cintaratu telah mampu menjadi pemasok untuk pasar hingga rumah makan.

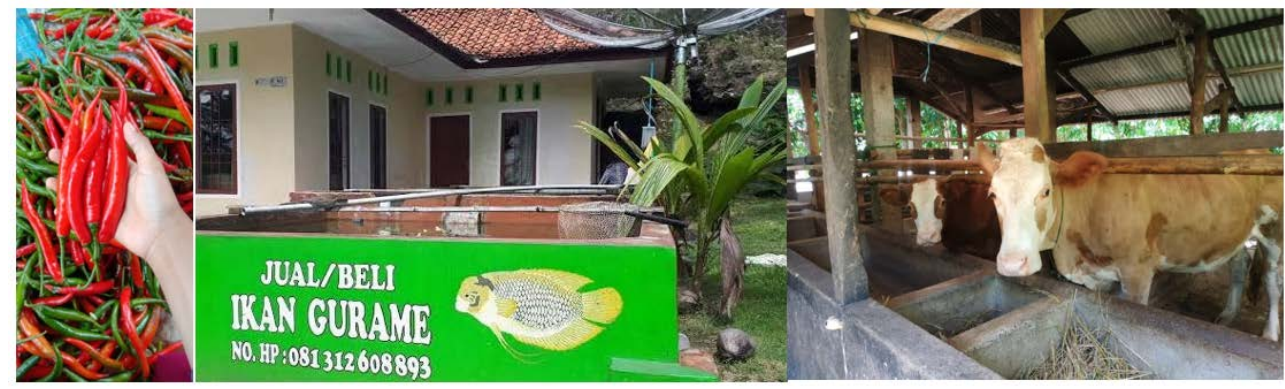

Gambar 3. Hasil sumber usaha ektraktif di Desa Cinta Ratu

Kelompok ternak Bintang Harapan melakukan penjualan kepada pengepul. Adapun peternak sapi individu, yakni Bapak Rupin, melakukan
Untuk memahami jaringan komunikasi bisnis usaha ekstraktif di Desa Cintaratu kita dapat melihat pada gambar dibawah ini: 


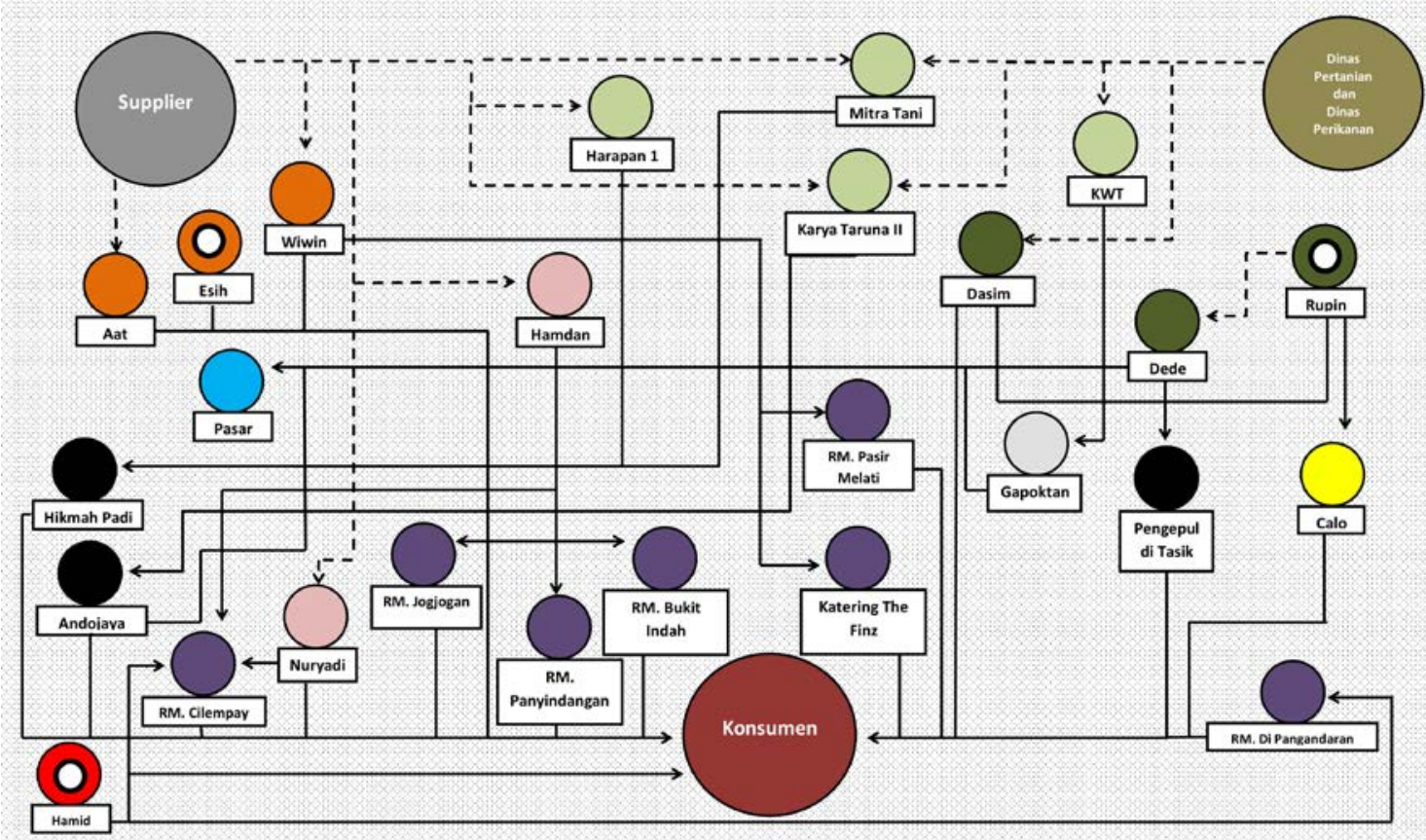

Supplier

Dinas Pertanian dan Perikanan

Kelompok Tani

Peternak Sapi

OPeternak Ayam

Pengepul

OBudidaya Ikan

OPasar

Calo

Rumah Makan

Pertanian dan Budidaya Ikan

Gapoktan

$\rightarrow$ Dari Supplier

$\rightarrow$ Penjualan

OPeranakan dan/atau Pemijahan

\section{Gambar 4. Peta Jaringan Komunikasi Bisnis Usaha Ekstraktif di Desa Cintratu}

Dalam peta jaringan komunikasi bisnis diatas, dapat dilihat terdapat dua aktor yang secara dominan memberikan supply kepada banyak pelaku usaha ekstraktif di Desa Cintaratu, yakni supplier serta Dinas Pertanian dan Dinas Perikanan. Kedua aktor tersebut memberikan input awal berupa bibit, pupuk maupun benih. Input yang diberikan tersebut diterima oleh masing-masing pelaku usaha ekstraktif untuk diolah sesuai dengan sektor yang digelutinya.
Pelaku usaha yang tergambar dalam peta jaringan komunikasi bisnis tidak hanya pelaku individu namun juga kelompok tani hingga rumah makan.

Melalui peta jaringan komunikasi bisnis dapat dilihat pola bisnis yang dilakukan oleh seluruh pengusaha bisnis usaha ekstraktif di Desa Cintaratu. Dimulai dari sektor pertanian, hasil pertanian di Desa Cintaratu cukup beragam mulai dari hasil pangan hingga 
holtikultura. Dalam jaringan komunikasi bisnis yang dijalin, kebanyakan petani bergerak sebagai kelompok tani dan menjual hasil pertaniannya melalui pengepul. Pengepul tersebut selanjutnya menyalurkan hasil pertanian kepada konsumen dan rumah makan. Gapoktan juga memiliki peranan dalam mengumpulkan hasil pertanian untuk selanjutnya didistribusikan ke pasar. Sektor peternakan menunjukkan pola komunikasi yang serupa, dimana peternak menjual hasil ternaknya melalui pengepul sebelum diterima konsumen akhir dan rumah makan. Salah satu peternak sapi telah mampu menjadi supplier bagi peternak lainnya. Hal ini menunjukkan potensi Desa Cintaratu untuk menjadi sentra peranakan sapi. Disisi lain peternak ayam melakukan penjualan secara langsung kepada konsumen akhir dan pengusaha catering. Dari sektor perikanan jaringan komunikasi bisnis yang dijalin juga serupa, hanya saja hasil perikanan dijual langsung kepada konsumen maupun rumah makan tanpa melalui perantara terlebih dahulu.

Beberapa permasalahan yang dapat dilihat melalui peta jaringan komunikasi bisnis ini adalah adanya pelaku usaha yang tidak memiliki akses untuk melakukan penjualan langsung kepada konsumen akhir. Pelaku usaha seperti Bapak Rupin yang bergerak dibidang peternakan sapi nampak hanya melakukan penjualan kepada calo dan pengepul. Secara potensi usaha yang dimiliki cukup besar karena peternakan tersebut telah mampu menjadi supplier bagi peternak lain. Peternakan milik Bapak Rupin juga tidak memerlukan pasokan benih dari Dinas maupun supplier lain dikarenakan telah mampu menjadi lokasi peranakan sapi. Bila pelaku usaha seperti ini memiliki jalur bisnis yang lebih luas dan direct kepada konsumen tentunya keuntungan yang dihasilkan dapat lebih besar. Contoh semacam ini juga bisa ditemukan dibidang pertanian. Sebagian petani/kelompok tani tidak memiliki akses langsung kepada konsumen akhir. Intervensi perlu dilakukan pada kasus-kasus seperti ini untuk meluaskan cakupan pasar dan mengoptimalkan potensi para pelaku usaha ekstraktif di Desa Cintaratu.

\section{SIMPULAN}

Usaha ektraktif di Desa Cintaratu menyimpan potensi yang cukup besar untuk digali. Hasil pertanian, peternakan dan perikanan yang dimiliki desa ini sungguh beragam. Dapat kita lihat pula sebagian pelaku usaha telah mampu menjadi supplier bagi pelaku usaha yang lain. Dalam beberapa kasus terlihat pula terdapat pelaku usaha yang melakukan penjualan secara langsung kepada konsumen maupun melalui calo dan pengepul. Peta jaringan komunikasi ini juga menunjukkan bahwa pelaku usaha bisnis ekstraktif di Desa Cintaratu telah mampu memenuhi kebutuhan beberapa rumah makan dan usaha catering yang ada di Desa Cintaratu. Masalah yang dapat ditemui dari jaringan komunikasi bisnis usaha ekstraktif di Desa Cintaratu adalah masih banyaknya pelaku usaha yang tidak memiliki akses langsung kepada konsumen. Hal yang dapat dilakukan adalah memberikan penyuluhan kepada pelaku usaha agar mulai melakukan atau menambah jumlah penjualan secara langsung ke pasar maupun ke konsumen akhir. Hal ini akan memberi dampak yang lebih besar kepada pelaku usaha saat terjadi kenaikan harga. Selain itu upaya untuk meningkatkan kemampuan marketing pada pelaku usaha juga perlu dilakukan untuk meluaskan pangsa pasar para pelaku usaha di Desa Cintaratu. Penggunaan teknologi yang lebih modern juga dapat dilakukan untuk meningkatkan produktivitas diseluruh sektor sumber usaha ekstraktif di Desa Cintaratu.

\section{UCAPAN TERIMAKASIH}

Ucapan terimakasih kami sampaikan kepada perangkat Desa Cintaratu yang telah memberikan arahan dan informasi awal yang menjadi pondasi awal dalam pelaksanaan penelitian ini. Kami juga berterimakasih kepada seluruh pelaku usaha ekstrakif Desa Cintaratu yang telah memberikan informasi yang berharga untuk mendukung penelitian ini. Tidak lupa ucapan terima kasih kami sampaikan kepada masyarakat Desa Cintaratu dan mahasiswa PSDKU Pangandaran yang telah membantu dalam pelaksanaan penelitian ini. 


\section{DAFTAR PUSTAKA}

Abdoellah, O. S., Sunardi, Widaningsih, I., Cahyandito, M. F., Wiyanti, D. T., \& Nurseto, H. E. (2019). Pengembangan Ekowisata Berbasis Masyarakat Di Desa Tarumajaya, Hulu Sungai Citarum: Potensi Dan Hambatan. Kumawula , 2 (3), 236-247.

Abdoellah, O. S., Sunardi, Widianingsih, I., \& Cahyandito, M. F. (2019). Pemetaan Sosial Dalam Perencanaan Program Pengembangan Ekowisata Berkelanjutan Citarum Harum Hulu, Kabupaten Bandung. Kumawula , 2 (1), 59-71.

Bantacut. T. (2012). Bisnis Berkelanjutan: Integrasi Manajemen Lingkungan dalam Pengelolaan Usaha. Agrimedia Vol. 17 no.1 Juni 2012.

Brown, T. (2013). Design Thinking. Harvard Business Review, 1-11.

Cochran, M. (1986). The parental empowerment process: Building on family strengths. In J. Harris (Ed.), Child psychology in action: Linking research and practice (pp. 12-33). Brookline, MA: Croon Helm Publishers

Rogers E.M. and. Kincaid. D.L. (1981). Communication Network: Toward A New Paradigm for Research. A Division of Mc Millan Publishing Co. Inc, New York.

Akses Internet. 2018. Geografis Desa Cintaratu. https://cintaratu.desa.id/geografis/ 